\author{
JANA JUŘÍKOVÁ \\ MAsARYK UniveRsity, CZECH RePUBLIC \\ Department of Kinesiology, Faculty of Sports Studies
}

\title{
Sedentary employees and their attitude to sport
}

\begin{abstract}
This study has used the questionnaire method to find out whether and to which extent persons engaged in sedentary employment, devote their leisure time to physical activities. Respondents were 70 employees working in the office. Examination of anthropometric parameters revealed that $45.6 \%$ of the respondents is overweight or obese, some persons confirmed overweight or obesity occurrence in the family history and in other family members. Merely $40 \%$ of respondents were satisfied with their bodies. However, in their leisure time, most respondents perform sports activity only occasionally or not at all.
\end{abstract}

\section{Introduction}

Hypokinesia, or in other words insufficient physical activity, has been gaining much attention lately. The present stage of technological development directly influences the lifestyle of a person both in and away from work. The vast majority of working operations are characterized by a lack of movement and are performed in a sitting position. The sitting position is generally considered a relaxed position, where the fewest muscle groups are activated. In many occupations, however, the sitting position, which was originally intended for rest, has become a permanent working position with no sufficient adaptation (Gilbertová 1984). There are an increasing number of office jobs performed at the computer, which goes hand in hand with an increasing number of sedentary employees. The sitting position is also convenient for number of working operations performed in factories. Even though the sitting may not be ideal, it is considered to be less tedious than 
standing. Compared to the standing position it requires lower energy output, lower strain on the cardiovascular system, especially the heart, and static load is also decreased. A sitting position enables better co-ordination and more precise work results, and it reduces congestion of the lower limbs.

On the other hand, sitting, especially for long periods, has its negative aspects too. These are primarily pronounced in the musculoskeletal system, particularly the spine, in the form of changes in muscular tonus and consequent incorrect body posture. Sedentary behaviour has recently emerged as an independent risk factor associated with several detrimental health outcomes (Thorp et al. 2011; Proper et al. 2011; Zvonař 2014). Sedentary and overweight or obese individuals have a greater risk for developing insulin resistance, a precursor to type 2 diabetes (Manson et al. 2004).

An average citizen of the Czech Republic aged $>15$ spends 375 minutes a day in the sitting position; this number is slightly lower in Poland - 333 minutes. Sedentary employment (i.e. employment which requires more than 7 hours a day) is performed by more than $35 \%$ of Czechs and $30-34.9 \%$ of Poles - see picture 1 .

A geographical pattern was observed, with higher percentages in north-western countries. European countries having $\geq 30 \%$ of the sample in the highest quartile. In contrast, south-western European countries typically had the lowest proportions within the highest quartile (Bennie et al. 2013).

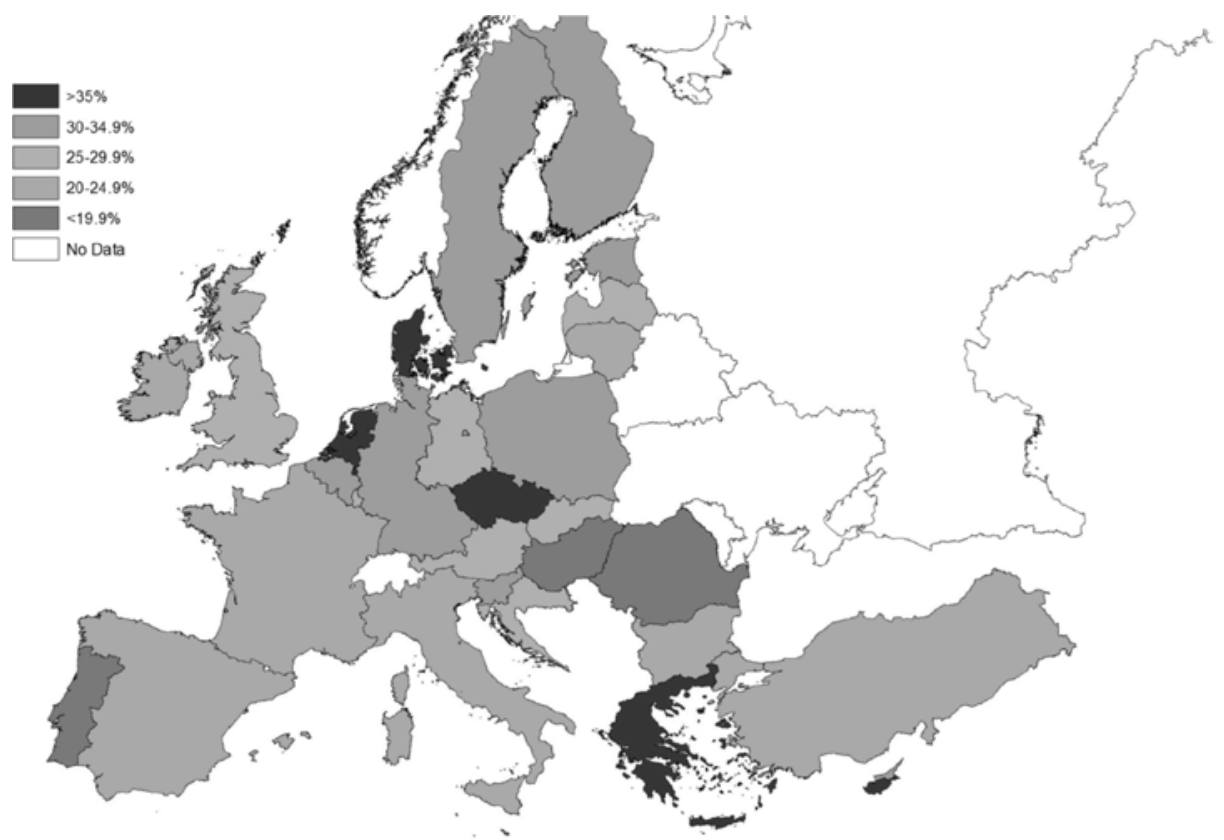

Picture 1. Percentage of people 15 years and older who sit for 7 or more hours per day by country

Source: Bennie et al. 2013. 
To prevent or lower the negative impacts of a sedentary lifestyle it is recommended to integrate some kind of physical activity in your leisure time. Regular exercise is one of the most cost-effective strategies for improving health and reducing metabolic disease risk (Gaziano et al. 2007; Skleryk et al. 2013).

Physical activity represents an integral part of a healthy lifestyle. From birth man is equipped to move easily and, especially for children, movement brings joyous feelings and pleasures. However, recently there has been an increase in more sedentary pastimes, not only in adults but in children as well. The moments of adventure children previously experienced during their games and outdoor physical activities, are now provided virtually through their computers or television screens. Thus children spend more time sitting, with no desire for physical exertion. Lack of movement and a steady increase in the popularity of unhealthy "fast food" snacks have a great impact on the prevalence of overweight, obesity and associated diseases. This is not only a cosmetic problem, but a serious health hazard. Despite the fact that genetic dispositions obviously play a major role, recent studies have discovered the connection between overweight and intense and frequent stress, lack of exercise and poor dietary habits. One of the most important prerequisites for maintaining reduced weight is physical activity. Stimulation and motivation for proper self-esteem and self-control are essential not only in obesity prevention, but in the prevention of health risks in general. Healthy lifestyle education can have a significant impact on life quality from childhood to old age (Krejčí 2007). Quality of life is limited by genetic dispositions, environment, way of life, standard of living, life satisfaction. Feeling good is closely related to physical fitness, personal habits, positive attitude to life, dealing with stress, nutrition and weight control (Křivohlavý 2001).

Physical activity is a crucial factor for human health. It helps build bone structure and supports muscles and joints. It also helps to maintain body weight and to reduce body fat (Ganiats et al. 1998). Studies show that physical activity is beneficial to maintaining good mental health, and reducing symptoms of depression, anxiety and stress generally (Dunn et al. 2001). Physical activity contributes to the prevention of and, in some cases, also the reduction of high blood pressure.

Sport and physical activity represent one of the basic phenomena of human existence and it takes place in all aspects of modern society. It represents one of the basic elements contributing to the quality of life and health.

The aim of the study was to discover the attitudes of sedentary employees towards sport: to what extent do they consider sport as frequent pastime or do they consider it an unimportant part of their lives to which they cannot bother to devote their time.

\section{Material and methodology}

The research group comprised of administrative staff of Military University of the Ground Forces in Vyškov (further as VVŠ), with sedentary jobs and no daily physical activities required (20 persons in total), accountants (13 persons), social 
security staff ( 25 persons) and members of Fire brigade in Prostějov who are not involved in firefighting processes, thus their job does not put physical exertion on them (12 persons) - 50 members of Fire brigade in total, further referred as HZS. The research covered 20 persons of VVŠ and 50 persons of HZS in total. Detailed enumeration of persons involved in the research is given in table 1.

Table 1. Persons involved in research

\begin{tabular}{|l|c|}
\hline \multicolumn{1}{|c|}{ Group of people } & No. of persons \\
\hline VVŠ males & 10 \\
\hline VVŠ females & 10 \\
\hline VVŠ - in total & 20 \\
\hline HZS males & 29 \\
\hline HZS females & 21 \\
\hline HZS - in total & 50 \\
\hline Total no. of persons & 70 \\
\hline
\end{tabular}

The research involved 70 persons in total (39 males and 31 females) whose employment might be characterized as sedentary. By the means of questionnaire method, the authors have examined respondents' nutrition habits and physical activities they perform in their leisure time. This study presents solely the analysis of respondents' answers concerning their physical activity and subjective perception of their health status and body weight.

First, the anthropometric parameters of respondents were collected. Respondents gave their age and consequently their body height and weight were measured. On the base of these data body mass index (BMI) was calculated. Afterwards the respondents were given anonymous questionnaire to fill in.

Body weight was measured on medicine scale by Soenhle Company, with the accuracy to $0.1 \mathrm{~kg}$. The examined person entered the scale in underclothes, barefoot. The weight of underclothes was not taken into account.

Body height was measured by anthropometry which was the part of medicine digital scale, accuracy to $0.1 \mathrm{~mm}$. The examined person stood straight, heels together, tips slightly apart, arms along the body, head vertically upward (Juříková et al. 2001).

Body mass index was calculated according to following relation:

$$
\mathrm{BMI}=\frac{\text { body weight }[\mathrm{kg}]}{(\text { body height }[\mathrm{m}])^{2}}
$$


Obesity classification according to BMI is given in table 2 .

Table 2. BMI categories, obesity classification (in accordance with WHO) and links to health risks

\begin{tabular}{|c|c|c|}
\hline BMI & Categories according to WHO & Health risks \\
\hline$<18.5$ & underweight & malnutrition, anorexia \\
\hline $18.5-24.9$ & normal & minimal \\
\hline $25.0-29.9$ & preobesity (overweight) & 25-26.9 slightly increased \\
\hline $30.0-34.9$ & obesity of $1^{\text {st }}$ grade & medium high \\
\hline $35.0-39,9$ & obesity of $2^{\text {nd }}$ grade & very high \\
\hline$>40$ & obesity of $3^{\text {rd }}$ grade & of \\
\hline
\end{tabular}

Source: Gauner 2001.

World Health Organization defines obesity when BMI exceeds 30, BMI higher than 40 stands for the term of morbid obesity. Not only the amount of fat itself, but also its distribution within the body represents important factors to assess the risks properly. Body mass index categorization as well as categorization of other biological characteristics shows the importance of natural variability. Such terms as "overweight" and "obesity" are used for particular specification of BMI values (Ganiats et al. 1998; Gailiūnienè et al. 2002). For population of people living in the Czech Republic, BMI ranges for males and females were recommended as shown in table 3.

Table 3. Categories of BMI range for males and females

\begin{tabular}{|c|c|c|}
\hline Category & Males & Females \\
\hline Thin & $<18.0$ & $<17.0$ \\
\hline Lean & $18.0-23.0$ & $17.0-22.0$ \\
\hline Relevant & $23.1-25.0$ & $22.1-24.0$ \\
\hline Chunky & $25.1-30.0$ & $24.1-30.0$ \\
\hline Obese & $>30.0$ & $>30.0$ \\
\hline
\end{tabular}

Source: Brázdová, Kleinwächterová 2001.

\section{Results and discussion}

The research concerning physical activity of persons with sedentary employment covered civil employees of Military University of the Ground Forces in Vyškov (further as VVŠ), and employees of Fire brigade in Prostějov with sedentary jobs, further referred as HZS. The research covered 70 persons in total. Distribution of focused group with respect to BMI categories is given in table 4 and graph 1. 
Table 4. Categorization of persons according to BMI (no. of persons)

\begin{tabular}{|l|c|c|c|c|c|c|}
\hline \multirow{2}{*}{$\begin{array}{c}\text { Group of } \\
\text { persons }\end{array}$} & \multicolumn{7}{|c|}{ Categories according to BMI } \\
\cline { 2 - 7 } & $\begin{array}{c}\text { Under- } \\
\text { weight }\end{array}$ & $\begin{array}{c}\text { Normal } \\
\text { weight }\end{array}$ & $\begin{array}{c}\text { Over- } \\
\text { weight }\end{array}$ & $\begin{array}{c}\text { Obesity of } \\
\mathbf{1}^{\text {st }} \text { grade }\end{array}$ & $\begin{array}{c}\text { Obesity of } \\
\mathbf{2}^{\text {nd }} \text { grade }\end{array}$ & $\begin{array}{c}\text { Obesity of } \\
\mathbf{3}^{\text {rd }} \text { grade }\end{array}$ \\
\hline VVŠ male & 0 & 7 & 3 & 0 & 0 & 0 \\
\hline VVŠ female & 0 & 8 & 2 & 0 & 0 & 0 \\
\hline HZS male & 0 & 14 & 11 & 3 & 1 & 0 \\
\hline HZS female & 0 & 9 & 10 & 2 & 0 & 0 \\
\hline
\end{tabular}

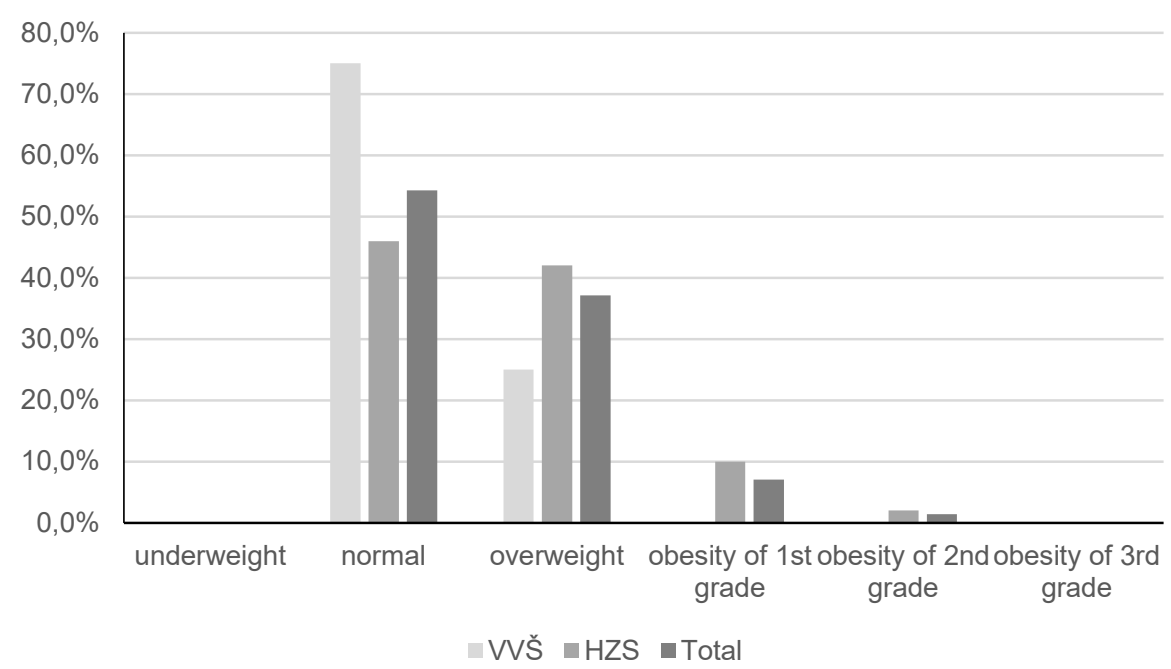

Graph 1. Categorization of persons according to BMI (percentage)

Reading the table and graph we will realize that normal body weight was found in 38 persons, which figure stands for approximately one half of respondents (54.3\%). Overweight was found in 26 persons (37.1\%). No obesity case was found among VVŠ employees. Five persons of HZS (7.1\%) belonged to obesity of $1^{\text {st }}$ grade category and 1 person $(1.4 \%)$ suffered by obesity of $2^{\text {nd }}$ grade. Within the whole tested group, increased BMI value was found in $45.6 \%$ of persons. 
Average values of BMI found in males and females are given in graph 2.

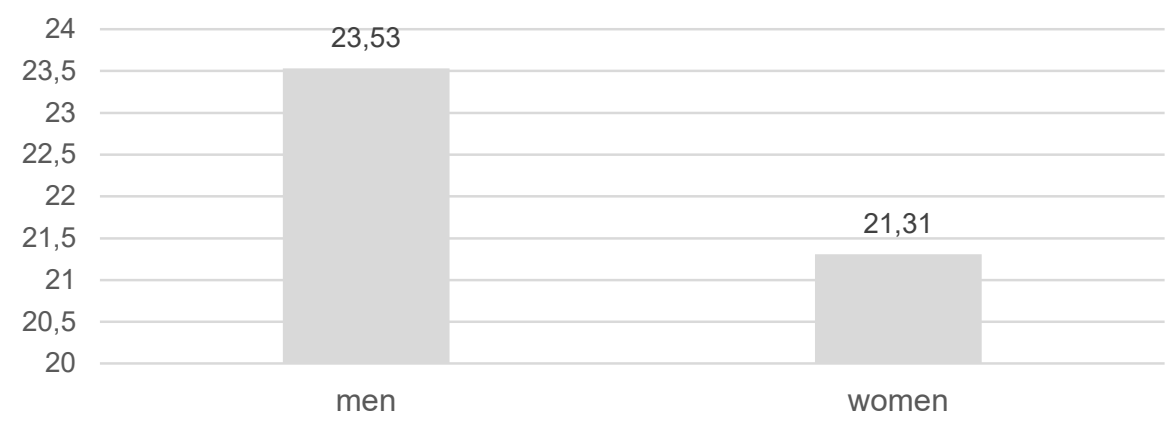

Graph 2. Average values of BMI in group of respondents

The results point to the fact that women generally mind their body weight more than men (Hrubá 2003).

$\mathrm{BMI}$ value is closely related to an appropriate body. Answers to the question concerning the contentment with respondent's own body are shown in table 5 and graph 3.

Table 5. Self-assessment of the body in group of respondents

\begin{tabular}{|l|c|c|c|}
\hline \multirow{2}{*}{ Group of persons } & \multicolumn{3}{|c|}{ Contentment with body } \\
\cline { 2 - 4 } & Need to gain weight & Satisfied & Need to lose weight \\
\hline VVŠ employees & 2 & 8 & 10 \\
\hline HZS employees & 5 & 20 & 25 \\
\hline Total & 7 & 28 & 35 \\
\hline
\end{tabular}

It is obvious that $40 \%$ of all respondents are content with their body. This corresponds the fact that $54.3 \%$ of respondents are in the normal range of BMI. Eight percent of VVŠ employees and $10 \%$ of HZS employees are of the opinion that they need to gain some weight, even though none of them belong to category underweight - see table 4. One half of both VVŠ and HZS employees expressed their wish to lose some weight. Since overweight and obesity was found in $45.6 \%$ of respondents, we can assume that $4.6 \%$ of them wish to lose weight, despite the fact that their BMI is considered to be normal. The wish to slim down was particularly pronounced among women. More recent research also indicated that although a relationship between body satisfaction and self-esteem exists in both men and women, this relation may be stronger for women than it is for men (Carraca et al. 2011; Safir et al. 2005; Najam, Ashfaq 2012). Eight percent of VVŠ and $10 \%$ of HZS employees would like to gain weight. 


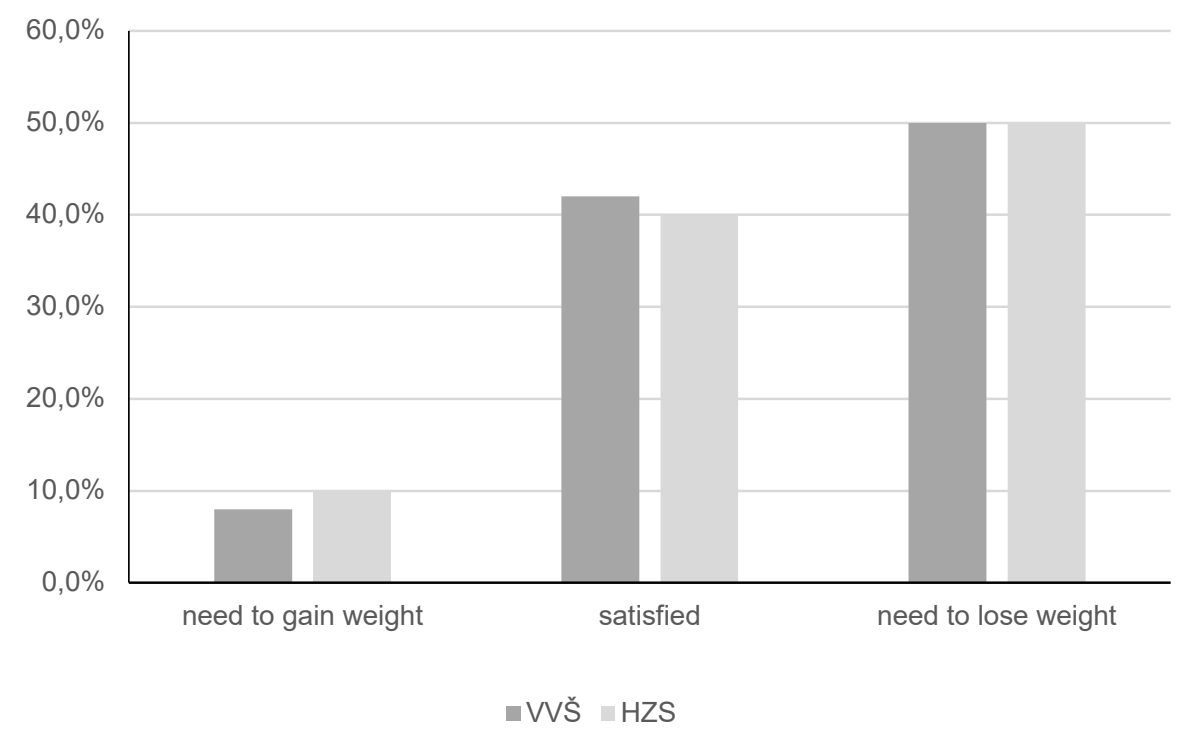

Graph 3. Self-assessment of the body in group of respondents

Overweight and obesity is tightly connected with health problems too. Following question aimed the fact if respondents perceive any health problems which might be connected with overweight or obesity. Respondents' answers are shown in table 6 and graph 4.

Table 6. Health problems occurrence connected with overweight

\begin{tabular}{|l|c|c|}
\hline \multirow{2}{*}{ Group of persons } & \multicolumn{2}{|c|}{ Health problems } \\
\cline { 2 - 3 } & 6 & nos \\
\hline VVŠ employees & 18 & 14 \\
\hline HZS employees & 24 & 32 \\
\hline Total & & 46 \\
\hline
\end{tabular}

From both the graph and the table it is obvious that about one third of respondents reported health problems which might possibly be connected with high weight. According to the BMI, $45.6 \%$ of respondents suffer from overweight or obesity, thus it was not found that every person suffering from overweight or obesity has the same time health problems arising from their weight. The most frequent health problems connected with overweight or obesity reported by respondents was hypertension. Many respondents also reported backache. This, however, is more likely connected with their sedentary employment. One respondent reported a pancreatic problem. Weight bias includes pervasive negative stereotypes and prejudice, for example, attributions of responsibility or competency, and can extend to actual discrimination in multiple domains of life, including health care (Puhl, Brownell 2001; Puhl, Heuer 2009; Hilbert et al. 2014). 


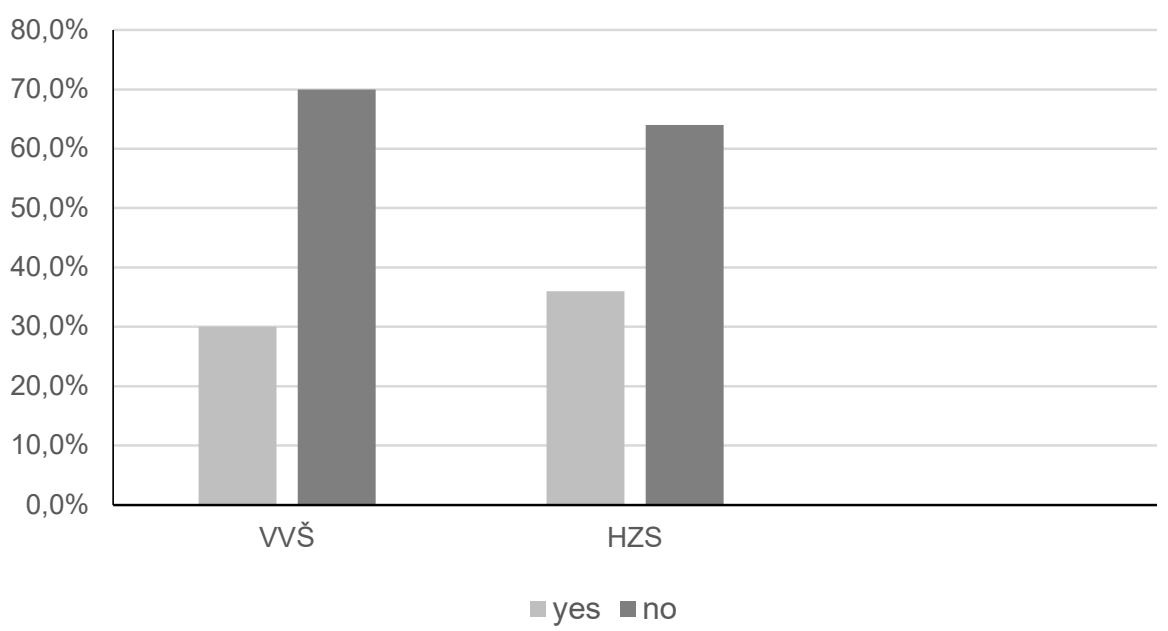

Graph 4. Health problems occurrence connected with overweight

Considering the fact, that heredity represents an important factor for overweight or obesity incidence, following question focused on the information whether there is an overweight or obesity incidence in respondents' families. The answers are given in table 7 and graph 5 .

Table 7. Overweight incidence in families of respondents

\begin{tabular}{|l|c|c|}
\hline \multirow{2}{*}{ Group of persons } & \multicolumn{2}{|c|}{ Overweight in family } \\
\cline { 2 - 3 } & yes & no \\
\hline VVŠ employees & 8 & 12 \\
\hline HZS employees & 21 & 29 \\
\hline Total & 29 & 41 \\
\hline
\end{tabular}

Both the table and graph show that overweight or obesity incidence in families is similar in both groups of respondents - $40 \%$ in VVŠ employees and $42 \%$ in $\mathrm{HZS}$ employees. This information corresponds with the findings of overweight or obesity in $45.6 \%$ of respondents. Many studies suggested that the risk of children becoming obese increased $50-80 \%$ when the parents were obese. The energy balance seemed to depend about $40 \%$ on genetic inheritance. It is worth pointing out that there is an overlap between heredity and dietary habits and behaviours shared by parents and children in the family environment (Portela et al. 2015; Orea 1997; Marques-Lopes et al. 2004). 


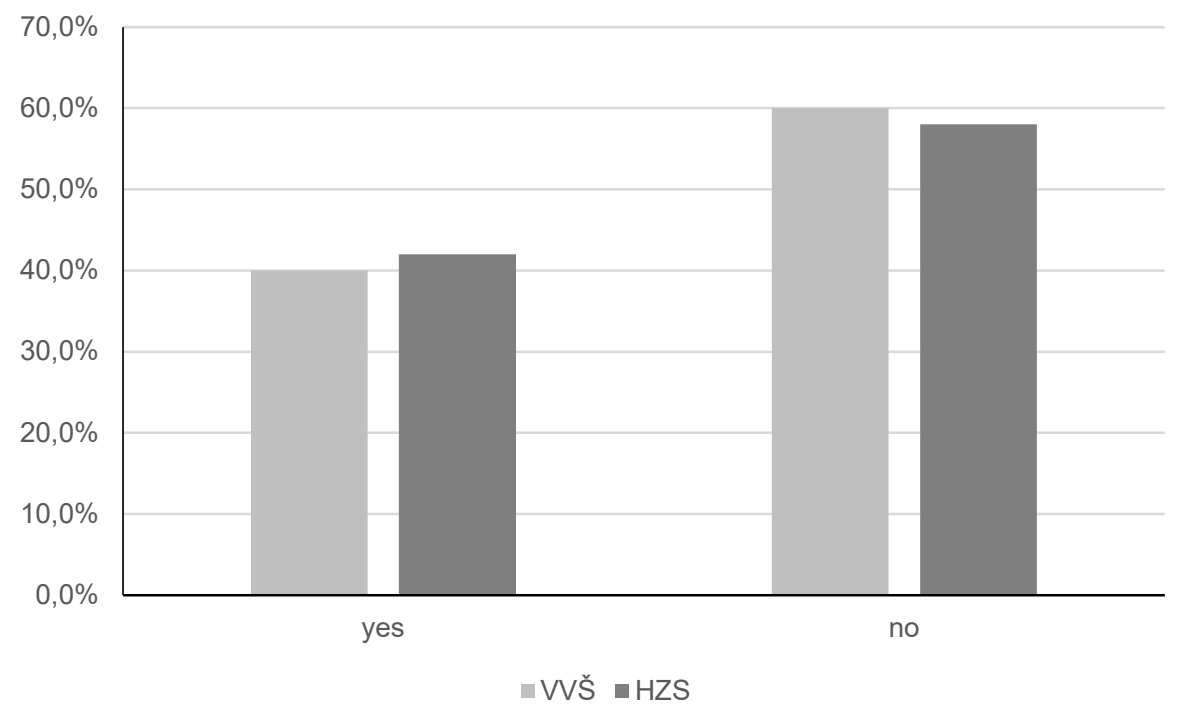

Graph 5. Overweight incidence in families of respondents

Overweight and obesity, as well as consequent quality of life deterioration and possible health problems, can be effectively combat by proper dietary habits and physical activity. Dietary habits have been already subjected to another study; following part will analyse the issues concerning physical activity.

To determine physical activity, respondents were given a selected offer of sport activities and they were asked to tick the sport they perform the most often. This was a semi-opened question, since respondents were supposed to choose the sport from pre-prepared offer, and in case they had not found their sport activity in the given list, they added their item in it. The most frequent sport activities are given in table 8.

Table 8. The most frequent sport activities performed by respondents

\begin{tabular}{|l|c|c|}
\hline \multirow{2}{*}{ Sport } & \multicolumn{2}{|c|}{ No. of respondents } \\
\cline { 2 - 3 } & Males & Females \\
\hline Hiking & 3 & 6 \\
\hline Running & 9 & 5 \\
\hline Cycling & 2 & 0 \\
\hline Swimming & 2 & 0 \\
\hline Aerobics & 0 & 7 \\
\hline Body building & 4 & 0 \\
\hline
\end{tabular}

Men the most often reported: running and body building. Body building was the most favourite sport activity among respondents, which is partially influenced by the fact that going to gym is nowadays a popular trends in common population. 
Women the most often reported aerobics, hiking and running. Other favourite sports of respondents were foot tennis, football and table tennis, for female also meditative activities (yoga, chi-kung).

The following question asked the respondents to subjectively assess their own physical activity by the means of Borgh scale from very low (evaluated by number 2 ) up to very high (evaluated by number 10). Results are given in graph 6.

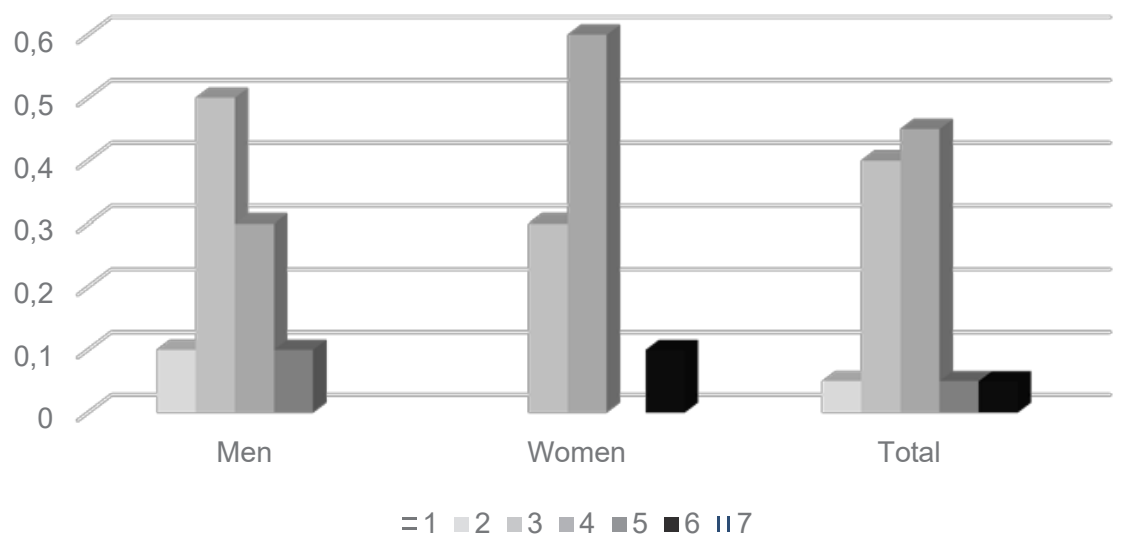

Graph 6. Subjective self-assessment of respondents' physical activity [\%]

The graph shows that $50 \%$ of men evaluated their physical activity by number 3 on scale, $60 \%$ of women by number 4 on scale. One woman reported daily physical activity of 60 min duration with intensity of 5 MET. ${ }^{1}$

Following question focused on the frequency of sport activity. Sport activity was defined as any sport activity, either in sport club, gym, swimming pool or at home. The answers are given in table 9, results in percentage are given in graph 7.

Table 9. Frequency of physical activity performed by respondents

\begin{tabular}{|l|c|c|c|c|c|}
\hline \multirow{2}{*}{ Group of persons } & \multicolumn{5}{|c|}{ Frequency of physical activity } \\
\cline { 2 - 6 } & $\begin{array}{c}\text { More than twice } \\
\text { per week }\end{array}$ & $\begin{array}{c}\text { twice per } \\
\text { week }\end{array}$ & $\begin{array}{c}\text { once per } \\
\text { week }\end{array}$ & occasionally & not at all \\
\hline VVŠ employees & 1 & 2 & 2 & 6 & 9 \\
\hline HZS employees & 1 & 3 & 3 & 30 & 13 \\
\hline Total & 2 & 5 & 5 & 36 & 22 \\
\hline
\end{tabular}

Table and graph show that merely 1 VVŠ and 1 HZS employee keeps recommended frequency for physical activities, i.e. three times a week as a minimum. Most respondents reported just occasional performance of physical activity

1 MET - exertion of the activity. Respondents were asked to assess the exertion within the scale 2 (very low) up to 10 (very high) (Brázdová, Fiala 1998). 


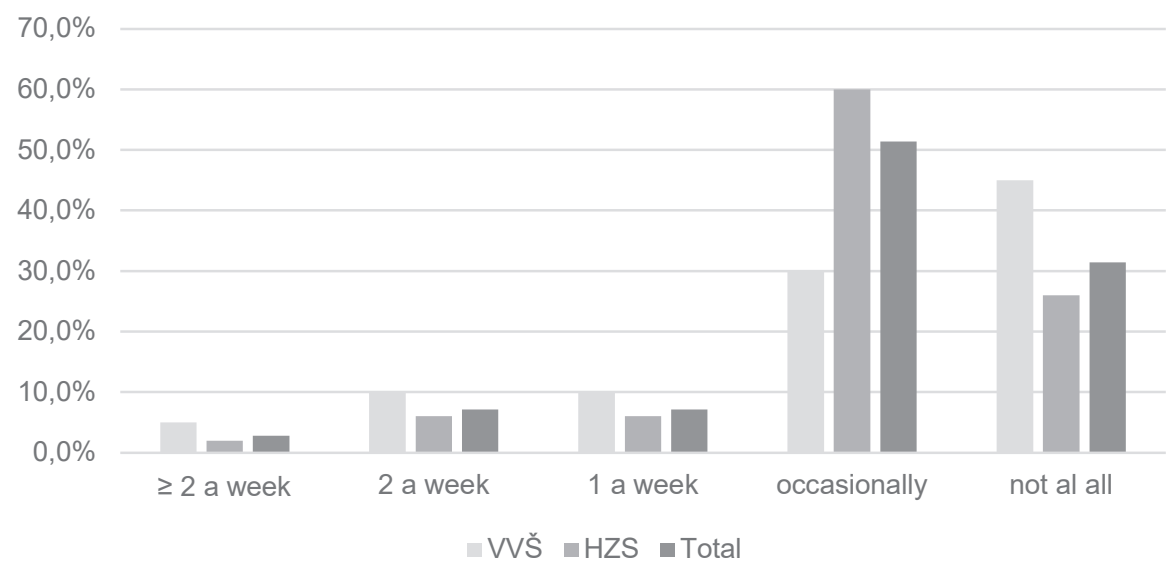

Graph 7. Frequency of physical activity performed by respondents

(51.4\%), while $45.0 \%$ of VVŠ employees and $26.0 \%$ of HZS employees do not perform physical activity in leisure time at all.

Next question monitors number of minutes respondents devote to regular daily walk, for example to the office, shopping, for walks. The answers are shown in graph 8.

The graph shows that most administrative workers devote $5-15$ min to walk daily (this answer was given by $40 \%$ of both males and females).

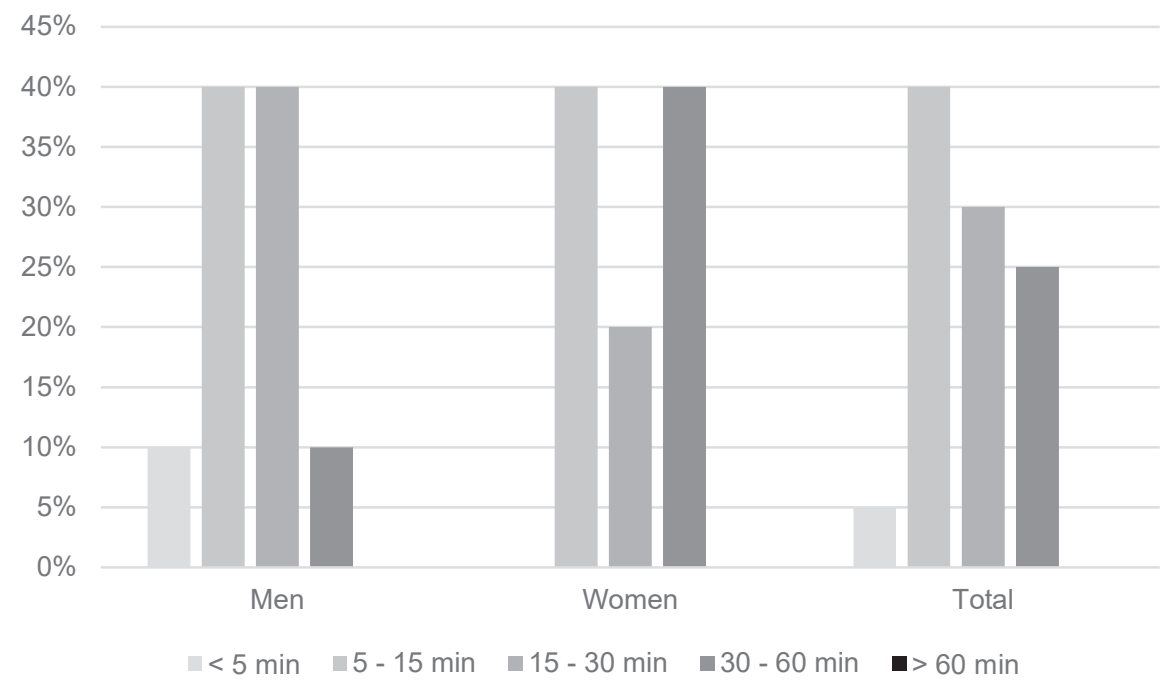

Graph 8. Duration of regular daily walks 


\section{Conclusion}

It was found that one half (54.3\%) of respondents has their BMI in normal value, thus they do not suffer from under or overweight. Overweight or obesity was defined in $45.6 \%$ of respondents, while $50 \%$ of respondents reported their subjective need to lose their weight. $8 \%$ of VVŠ and $10 \%$ of HZS employees reported contrary wish to gain the weight. Overweight or obesity is connected with health problems too these were reported by one third of respondents. Overweight or obesity incidence in other family members was identified in approximately $40 \%$ of respondents.

Considering sedentary employment of respondents, any physical activity performed in their leisure time would be more than advisable. However, most respondents devote their leisure time to sport activity only occasionally (51.4\%) and more than one quarter of them (31.4\%) do not provide any sport at all. Merely one respondent reported frequency of sport activity more than twice a week. The most frequent sports are running and body building for men, and aerobics, hiking and running for women. The perceived exertion was subjectively assessed on scale 2-10; men mostly evaluated their physical activity by number 3 , while most women reported number 4 . Most respondents (40\%) spend 5-15 min walking daily. Walks would be very convenient and in the same time financially undemanding physical activity for this group of people.

\section{References}

Bennie J.A., Chau J.Y., van der Ploeg H.P., Stamatakis E., Do A., Bauman A., The prevalence and correlates of sitting in European adults - a comparison of 32 Eurobarometer-participating countries, "International Journal of Behavioral Nutrition and Physical Activity" 2013, 10, http://www.ijbnpa. org/content/10/1/107. Accessed 11 March 2015.

Brázdová Z., Kleinwächterová H., Výživový stav člověka a způsoby jeho zjišt'ování, Institut pro další vzdělávání pracovníků ve zdravotnictví, Brno 2001, p. 78-81.

Carraca E.V., Silva M.N., Markland D., Vieira P.N., Minderico C.S., Sardinha L.B., Teixeira P.J., Body image change and improved eating self-regulation in a weight management intervention in women, "International Journal of Behavioral Nutrition and Physical Activity" 2011, 75, http://www. ijbnpa.org/content/8/1/75. Accesed: 3 June 2015.

Dunn A., Trivedi M., O'Neal H., Physical activity dose - response effects on outcomes of depression and anxiety, "Medicine \& Science in Sports \& Exercise" 2001, 33, p. 597.

Gailiũniené A., Visagurskiené K, Sideravičiũté S., Body mass index, total cholesterole and triglycerides in blood of overweight and normal weight adolescent girls, "Education, Physical Training, Sport" 2002, 3, p. 15-18.

Ganiats T.G. et al., Expert Panel on the Identification, Evaluation and Treatment of Overweight and Obesiy in Adults: the Evidence Report, "Obesity Research" 1998, 6 (Supplement 2), p. 51-179.

Gauner V., Obezita, minimum pro praxi, Triton, Praha 2001, p. 109-113.

Gaziano T.A., Galea G., Reddy K.S., Scaling up interventions for chornic disease provention: the evidence, "Lancet" 2007, 370, p. 1939-1946. 
Gilbertová S., Sedavé zaměstnání a vertebrogenní onemocnění, "Rehabilitácia” 1984, 17, p. 151-161.

Hilbert A., Braehler E., Haeuser W., Zenger M., Weight bias internalization, core self-evaluation, and health in overweight and obese persons, "Obesity" 2014, 22, p. 79-85.

Hrubá A., Studium vztahu mezi výživou, fyzickou zátěží a obezitou, diploma thesis, Military university of ground forces, Vyškov 2003, p. 47-52.

Juříková J., Komár A., Kreuziger J., BMI jako prostředek posouzení přiměřené tělesné váhy a zdraví, "Vojenský profesionál" 2001, 1-2-3, p. 108-111.

Krejči M., Adequate movement regime in connection to mental health and mental hygiene, Oral presentation. International conference "Health Education and Quality of Life I", University of South Bohemia in České Budějovice, Hluboká nad Vltavou 2007, p. 35-42.

Křivohlavý J., Psychologie zdraví, Portál, Praha 2001, p. 45.

Manson J.A.E., Skerrett P.J., Greenland P., Vanltallie T.B., The escalating pandemics of obesity and sedentary lifestyle: a call to action for clinacians, "Arch Intern Med" 2004, 164, p. 249-258.

Marques-Lopes I., Marti A., Moreno-Aliaga M.J., Martinez A., Genetic of obesity, "Rev Nutr" 2004, 17, p. 327-338.

Najam N., Ashfaq H., Gender differences in physical fitness, body shape satisfaction, and body figure preferences, "Pakistan Journal of Psychological Research" 2012, 2, p. 197-200.

Orera M., Aspectos genéticos de la obesidade, [in:] Obesidad: presente y future, Biblioteca Aula Médica, Madrid 1997, p. 51-69.

Portela D.S., Vieira T.O., Matos S.M.A., de Oliveira N.F., Vieira G.O., Maternal obesity, environmental factors, cesarean delivery and breastfeeding as determinants of overweight and obesity in children: results from a cohort, "BMC Pregnancy \& Childbirth" 2015, 15, p. 94-103.

Proper K.I., Singh A.S., van Mechelen W., Chinapaw M.J., Sedentary behaviors and health outcomes among adults: a systematic review of prospective stuides, "Am J Prev Med" 2011, 40, p. 174-182.

Puhl R., Brownell K.D., Bias, discrimination, and obesity, "Obes Res" 2001, 9, p. 788-805.

Puhl R.M., Heuer C.A., The stigma of obesity: a review and update, "Obesity" 2009, 17, p. 941-964.

Safir M.P., Shimrit K.F., Rosenmann A., When gender differences surpass cultural differences in personal safisfaction with body shape in Israeli college sutdents, "Sex Roles" 2005, 5, p. 369-378.

Skleryk J.R., Karagounis L.G., Hawley J.A., Sharman M.J., Laursen P.B., Watson G., Two weeks of reduced-volume sprint interval or traditional exercise training does not improve metabolic functioning in sedentary obese men, "Diabetes, Obesity and Metabolism" 2013, 15, p. 1146-1153.

Thorp A.A., Owen N., Neuhaus M., Dunstan D.W., Sedentary behaviors and subsequent health outcomes in addults a systematic review of longitudinal studies, 1996 - 2011, "Am J Prev Med" 2011, 41, p. 207-215.

Zvonař M., Výzkum motorické výkonnosti populace, [w:] M. Zvonař et al., Aplikovaná antropomotorika II, Masarykova univerzita, Brno 2014, p. 8-20. 